Review

\title{
Long-Term Monitoring of Brain Dopamine Metabolism In Vivo with Carbon Paste Electrodes
}

\author{
Robert D. O’Neill \\ UCD School of Chemistry \& Chemical Biology, University College Dublin, Belfield, Dublin 4, \\ Ireland. \\ E-mail for correspondence: Robert.ONeill@UCD.ie
}

Received: 4 April 2005 / Accepted: 28 April 2005 / Published: 14 November 2005

\begin{abstract}
This review focuses on the stability of voltammetric signals recorded over periods of months with carbon paste electrodes (CPEs) implanted in the brain. The key interaction underlying this stability is between the pasting oil and brain lipids that are capable of inhibiting the fouling caused by proteins. In brain regions receiving a significant dopaminergic input, a peak due to the methylated metabolites of dopamine, principally homovanillic acid (HVA), is clearly resolved using slow sweep voltammetry. Although a number of factors limit the time resolution for monitoring brain HVA concentration dynamics, the stability of CPEs allows investigations of long-term effects of drugs, as well as behavioral studies, not possible using other in-vivo monitoring techniques.
\end{abstract}

Key words: in-vivo voltammetry; homovanillic acid; HVA; ascorbic acid; uric acid; diurnal changes; haloperidol; apomorphine; dopamine release; motor activity; benzodiazepines; food; review. 


\section{Introduction}

Dopamine (DA) is a catecholamine neurotransmitter released by neurons in a number of regions of the mammalian brain, and is thought to be important in the expression of a wide variety of behaviors [1-3]. DA in the basal ganglia is involved in motor control, and a causative link has been established between loss of DA in the dorsal striatum, due to neurodegeneration, and Parkinson's disease in humans [4]. In the prefrontal cortex, DA regulates cognitive functions [5]; DA imbalance in this region can lead to attention disorders and has been implicated in the pathophysiology of schizophrenia [6-9]. Another important role for DA has been established in the expression of 'rewarding' behaviors [10,11], such as eating [12,13] and sexual activity [14,15]. Indeed, many of the common drugs of abuse (e.g., cocaine [16], amphetamine [17] and 'ecstasy' [18]) have specific actions on brain DA systems, and this mechanism may be involved in the addictive properties of these agents. The ability to monitor a real-time index of DA release in discrete brain areas during well defined behaviors, and in response to pharmacological challenges, would provide an important key to understanding more fully the role this molecule plays in brain function.

A growing number of methodologies are being developed, including sampling [19,20], spectroscopic [21] and electrochemical [16,22,23], to study neurochemical phenomena in the intact brain. One such set of techniques focuses on the in-situ detection of substances in brain extracellular fluid (ECF), using in-vivo voltammetry (IVV) with implanted amperometric electrodes. A number of reviews on the principles and applications of IVV analysis of the ECF have been published, and a representative selection is cited here [24-39]. This paper reviews the application of one approach to monitoring neurochemical dynamics in brain extracellular space: the use of chronically implanted carbon paste electrodes (CPEs) that are stable enough to detect a metabolite of DA continuously over periods of months.

It should be stressed that the application of IVV involves far more than a straightforward transfer of expertise gained from the practice of voltammetry in vitro. In addition to being anatomically complicated and containing a wide range of electroactive substances, brain tissue presents a complex chemical environment that includes surfactants (lipids), electrodes poisons (proteins), electrocatalysts such as glutathione and ascorbate, and a tissue matrix that both restricts mass transport to the electrode surface and reacts physiologically to the presence of the probe [40]. Thus, the behavior of a particular electrode and voltammetric technique in vitro might well be different to its behavior in vivo, because both modification of the electrode surface by components of the tissue [41,42], and the differences in mass transport [43-46], could lead to different responses (sensitivity, selectivity, stability, etc.) in the two environments [47]. Therefore, detailed characterization in vitro of parameters such as detection limits is of little use, and may be misleading in an application like IVV where the major issue is that of selectivity rather that sensitivity. An example of the complications involved in characterizing an IVV technique in vivo is that of time scale: a technique demonstrated to detect DA selectively on a fast time scale (seconds) cannot be assumed to do so on slower time scales 
(minutes) because changes in neurotransmitter concentrations tend to be much faster than those of their metabolites [48]. Issues such as these have been addressed recently in the literature [49,50].

\section{Dopamine Biochemistry}

Figure 1 shows a schematic representation of intercellular chemical signaling at a synapse between a DA nerve terminal and target neuron. The precursor amino acid tyrosine is taken from the ECF into the terminal where tyrosine hydroxylase (rate-determining step) and DOPA decarboxylase

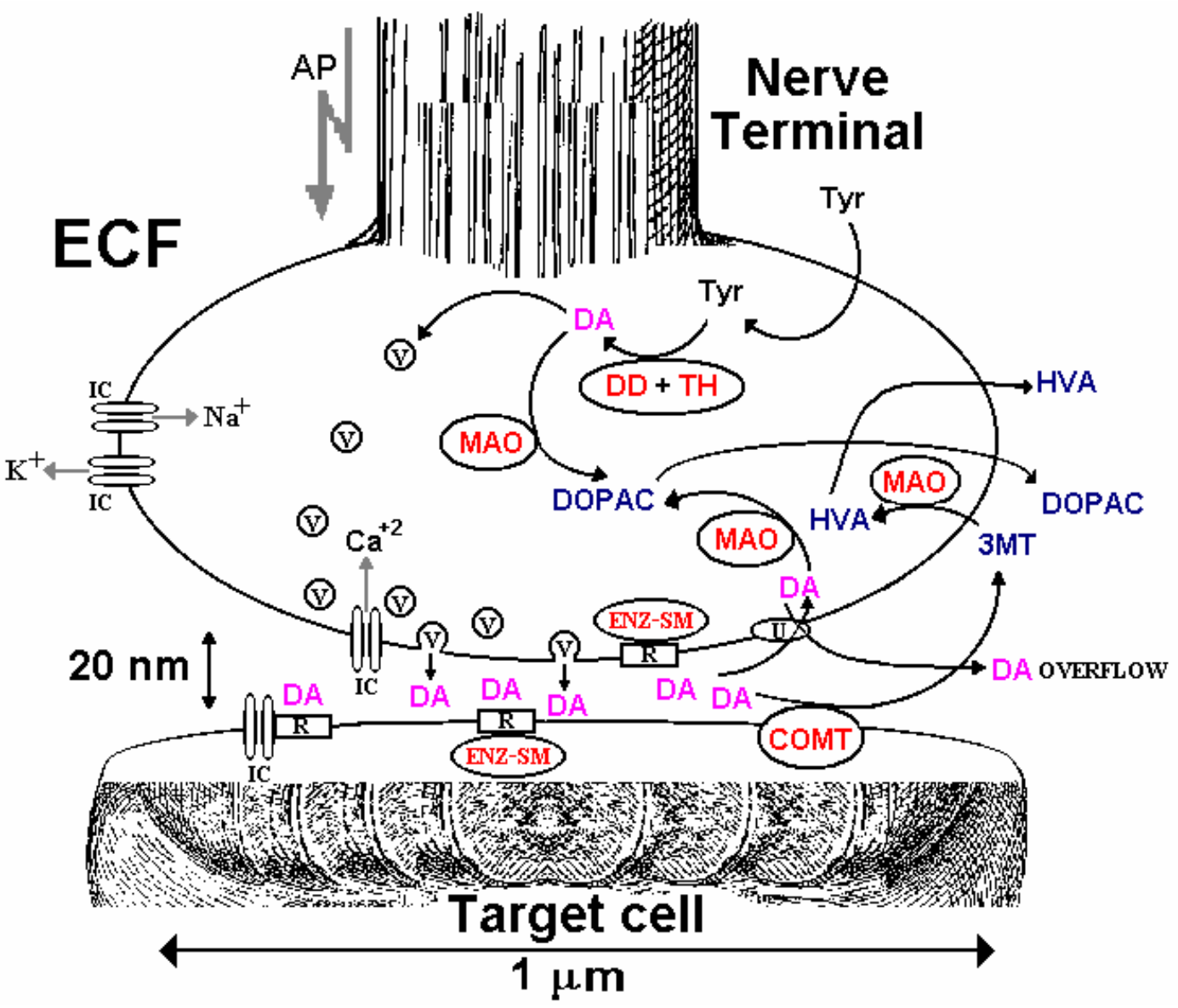

Figure 1. Schematic representation of a dopamine (DA) nerve terminal, including synthesis from tyrosine (Tyr) via tyrosine hydroxylase (TH) and DOPA decarboxylase (DD) and storage in vesicles (V). On arrival of an action potential (AP), the depolarization resulting from the influx of $\mathrm{Na}^{+}$leads to opening of $\mathrm{Ca}^{+2}$ ion channels (ICs). The consequent influx of $\mathrm{Ca}^{+2}$ causes a variety of biochemical cascades, one of which induces fusion of $\mathrm{V}$ and release of the stored DA. Metabolic enzymes involved in regulating the concentration of DA include monoamine oxidase (MAO) in the terminal and post-synaptic catechol-O-methyltransferase (COMT), producing mainly DOPAC and homovanillic acid (HVA). DA action is mediated by both pre- and post-synaptic receptors (R) that are linked to ICs or "second messenger" enzymes (ENZ-SM), such as adenylate cyclase. Levels of synaptic DA are also controlled by specific uptake channels (U), through which DA can also leak from the cytoplasm. Color code: grey (ionic events); red (enzyme-mediated processes); magenta (neurotransmitter, DA); blue (DA metabolites). See Figure 2 for further details of the biochemical pathways. 
transform it into the neurotransmitter DA. Although most of the newly synthesized neurotransmitter is taken up into storage vesicles, some will be inactivated before reaching the vesicles by metabolic enzymes present in the terminal, especially monoamine oxidase. When an action potential (rapid depolarization, followed by repolarization of the membrane potential; total duration about $5 \mathrm{~ms}$ ) propagates down an axon to the nerve terminal, voltage-sensitive $\mathrm{Na}^{+}$ion channels open, causing depolarization of the terminal membrane and the opening of voltage-sensitive $\mathrm{Ca}^{2+}$ channels, the influx of $\mathrm{Ca}^{2+}$, and fusion of vesicles that release their neurotransmitter content into the synapse; a few milliseconds later, the opening of voltage-sensitive $\mathrm{K}^{+}$channels results in repolarization (Figure 1). This $\mathrm{Ca}^{+2}$-dependent exocytotic release of neurotransmitter is surprisingly fast in the mammalian brain, occurring within microseconds of the start of the action potential upswing in the terminal [51].<smiles>CC(C)C(=O)O</smiles><smiles>NC(Cc1ccc(O)c(O)c1)C(=O)O</smiles><smiles>C1CC[Pb]C1</smiles><smiles>COc1cc(CCN)ccc1O</smiles><smiles>CC(=O)O</smiles><smiles>NCCc1ccc(O)c(O)c1</smiles><smiles>COc1cc(CC(=O)O)ccc1O</smiles><smiles>CC(C)C</smiles><smiles>COC(=O)OCc1ccc(O)c(O)c1</smiles>

Figure 2. Schematic representation of some of the biochemical pathways involved in the synthesis and metabolism of dopamine (DA). Precursor tyrosine is converted in the rate-determining synthesis step by tyrosine hydroxylase (TH) into L-DOPA whose cytoplasmic concentration is kept low by rapid conversion to DA by DOPA decarboxylase (DD). DA can be degraded into neuro-inactive forms by a number of pathways. The most important of these involve monoamine oxidase (MAO) and catecholO-methyltransferase (COMT) whose main products are 3,4-dihydroxyphenylacetic acid (DOPAC) and homovanillic acid (HVA). 3-Methoxytyramine (3-MT) is unusual among metabolites in that it has a higher affinity for the DA uptake carrier than DA itself [52] and therefore levels of 3MT in the ECF are very low [53]. See Figure 1 for anatomical context. 
Once in the synapse, the neurotransmitter molecules may bind to a range of different receptor proteins on either the presynaptic or postsynaptic membrane. On the presynaptic side, receptors may be linked to a "second messenger" enzyme involved in regulating the activity of the rate-determining enzyme used in the synthesis of neurotransmitter (local negative feedback control). Postsynaptically, receptors may also be linked to a second messenger system, or to ion channels for $\mathrm{Na}^{+}, \mathrm{K}^{+}$or $\mathrm{Cl}^{-}$that control the membrane potential of the target neuron. Inactivation of the chemical signal is achieved either by re-uptake of neurotransmitter into the terminal (and other sites, such as glial cells) through specific ion-coupled carrier uptake sites and subsequently metabolized, or may be metabolized extracellularly. The metabolites diffuse into the ECF that also contains a low concentration of neurotransmitter that overflows from the synapse (Figure 1).

One of the key elements in understanding the role of each neurotransmitter substance in neural networks is a knowledge of release rate, and Adams et al. [54] suggested that amperometric electrodes implanted directly in the intact brain might be used to monitor electroactive neurotransmitters in the CNS. However, electrodes generally employed for neurochemical analysis using IVV are $\sim 5-300 \mu \mathrm{m}$ in diameter and monitor an average concentration of analyte in the medium surrounding cells, the ECF, and not directly in synapses that are orders of magnitude smaller (typically 20-30 nm; see Figure 1). It is not clear at present what the relationship is between release of different neurotransmitters into the synapse and resulting ECF levels, although balance between release and re-uptake (Figure 1) is involved $[55,56]$. It is also debatable whether neurotransmitters released into a synapse have additional extrasynaptic functions, so that the synapse might be designed to 'leak'. For example, extrasynaptic receptors have been reported for the main excitatory CNS neurotransmitter, glutamate [57], as well as evidence for the diffusion of glutamate outside the synaptic cleft [58]. Thus, monitoring the overflow of transmitter in the ECF is one index of release rate. Another is the concentration of metabolite in the ECF, although caution is needed in the interpretation of metabolite data because changes in synthesis rate can also affect metabolite levels, independent of release [59-61].

\section{Carbon Paste Electrodes for In-Vivo Voltammetry}

Since its invention in the late 1950s [62], the CPE has continued to offer a versatile substrate for electroanalysis, mainly because of the ease with which the bulk or surface of this electrode material can be modified with inorganic, organic and biological molecules [63-67]. In addition to the neurochemical studies cited below, applications of CPEs include environmental monitoring [68,69], drug analysis [70-72], determination of heavy metals [73] and toxins [74], biomedical monitoring [66,75-79], and food analysis [80,81].

For applications involving implantation into biological tissues, carbon paste, prepared by thoroughly mixing carbon powder with either Nujol [54] or silicone oil [82] can be easily packed into cavities created by pulling the insulation over fine metal wires, producing disk electrodes of diameters as small as $160 \mu \mathrm{m}$, although diameters of about $300 \mu \mathrm{m}$ have been generally used for IVV (Figure 3). A carbon/Nujol paste electrode with $\mathrm{CV}$ was used in one of the first reports of voltammetry in brain 
tissue with the aim of studying DA [54]; a single peak was observed in rat striatum, attributed mainly to the oxidation of ascorbate. Decreasing the scan rate to $10 \mathrm{mV} / \mathrm{s}$ and semidifferentiation of the current later revealed three rather broad waves on the striatal voltammogram [83]. Further developments of the technique by the use of computer-controlled equipment [84], silicone oil paste [82], an additional reduction of the sweep rate to $5 \mathrm{mV} / \mathrm{s}$, abandoning semidifferentiation, and subtraction of the background current recorded in situ, yielded CPE voltammograms consisting of three well-separated peaks in striatal tissue [85] (see Figure 4).

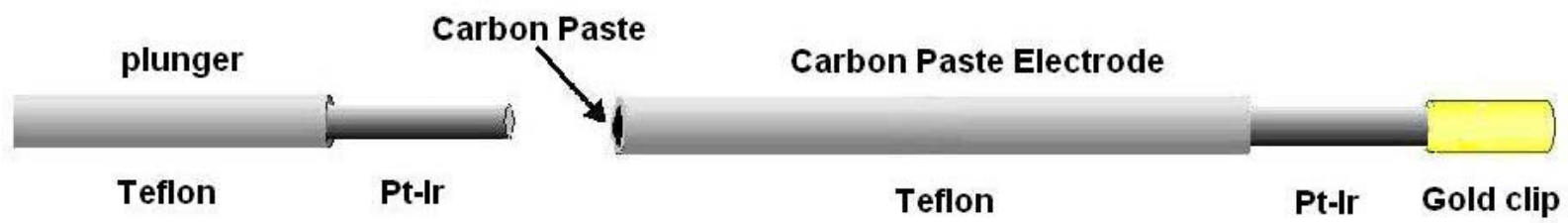

Figure 3. Schematic representation of an implantable CPE constructed from Teflon-coated wire. After soldering a gold clip to facilitate later connection to the potentiostat, a small cavity ( $\sim 0.5 \mathrm{~mm}$ long) is made by drawing the insulation over the metal wire (usually Ag or Pt-Ir). The carbon paste should be packed carefully into a cavity using a sleeved plunger of the same wire. If the paste is too loose or the cavity too short, the extracellular fluid may penetrate to the metal producing large background currents after a few days. If packed too tightly, the Teflon may crack, again allowing electrolyte into the cavity.
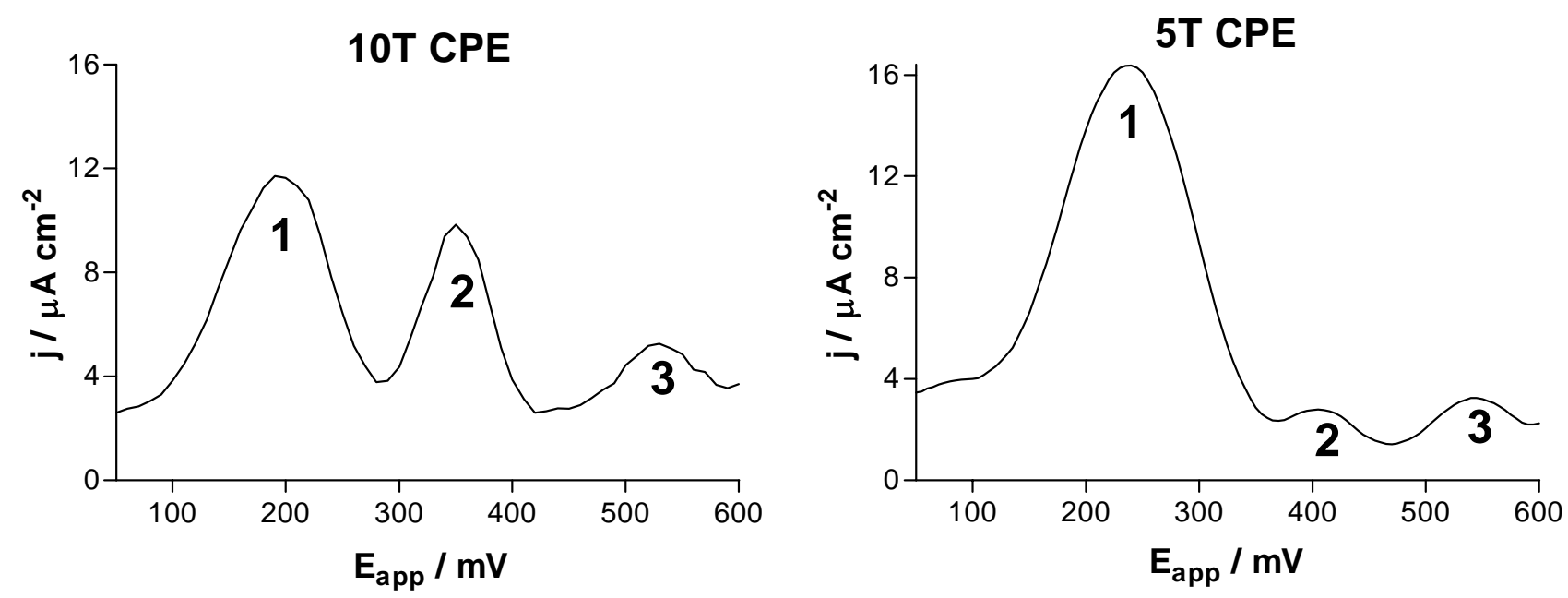

Figure 4. Samples of background-subtracted staircase voltammograms, expressed as current density, recorded at $5 \mathrm{mV} / \mathrm{s}$ with either $10 \mathrm{~T}(320-\mu \mathrm{m}$ diameter) or $5 \mathrm{~T}$ (160- $\mu \mathrm{m}$ diameter) CPEs (see Figure 3) chronically implanted in rat striatum for periods of up to 6 months. The main difference between the responses obtained with these two dimensions of CPE is the size and nature of peak 2. Both the absolute current density peak-2 height, and the relative contributions of 5HIAA and uric acid to this peak, are different because of differences in the extent of tissue reaction to the implanted electrodes [86-89]. 
Peak-shaped signals are obtained by this non-differential method due to both thin-layer behavior in the compartment around the implanted electrode $[43,90,91]$ and adsorption of the analytes $[41,88]$. Because of the lack of clear resolution between ascorbate and catechols by CPEs, a wide variety of techniques have been used to characterize the $\mathrm{CPE}$ signals recorded in rat striatum in vivo: theoretical analysis [91]; electrochemical studies in vitro [47,82,84]; microinfusion of microlitre solutions of candidate substances [84,92] and metabolizing enzymes [88,93-95] beside electrodes implanted in brain tissue; lesions to striatal afferent pathways [59,93,96]; pharmacological perturbations using drugs with well-characterized actions [59,87,92,94]; and comparison with other invivo techniques, such as microdialysis $[88,97]$.

These experiments have been reviewed [40] and indicate that peak 1 (see Figure 4) is due mainly to ascorbate; moreover changes in the height of peak 1 result from variations in the extracellular concentration of ascorbate, provided there is no significant shift in the relative potentials of peaks 1 and 2. When such potential shifts occur they are not due to electrocatalysis but to the algebraic combination of the ascorbate peak (at the normal potential of peak 1) and the catechol peak some $60 \mathrm{mV}$ higher, and difference voltammograms can be used to analyze the changes in terms of fluctuations in the catechol concentration [84]. Under most circumstances (some exceptions being stroke [98] and death $[99,100])$ these latter changes are mainly due to DOPAC, because the level of DA in striatal ECF has been estimated by a range of techniques to be less than $50 \mathrm{nM}$ [101-103]. The main component of peak 2 is uric acid with a minor contribution from the 5HT metabolite, 5HIAA, when $\sim 300 \mu \mathrm{m}$ CPEs are used [88], whereas peak 2 recorded with $160 \mu \mathrm{m}$ CPEs is due almost exclusively to 5HIAA [87]. Changes in the height of peak 3 are directly proportional to changes in the extracellular concentration of methylated metabolites of DA. Normally this is HVA [59] at an estimated baseline level of $10 \mu \mathrm{M}$ [92], but when monoamine oxidase is pharmacologically inhibited, 3MT may also contribute [97].

The main advantage of CPEs is their stability over several months of recording in vivo [24]. The evidence suggests that lipids present in the tissue remove pasting oil from the surface [35], making it more powder-like [104] and reversing the poisoning caused by proteins [47]; see Figure 5. An early study by Adams et al. [104] showed that certain carbon powders behave electrochemically like Pt, and that incremental addition of pasting materials reduced electron transfer rate constants $\left(k^{\circ}\right)$ for a variety of analytes. Furthermore, electrochemical pretreatment of the CPEs removed surface oil and tended to restore $k^{0}$ to the 'dry' limit. The increase in $k^{0}$ induced by lipid treatment has been observed for both Nujol $[42,105,106]$ and silicone oil $[41,47,107]$ based CPEs, although the time course of the effect is slower for the Nujol CPE presumably because of the higher oil content in the standard Nujol formulation for implantable CPEs. It appears that it is the continual process of oil removal by lipids and other surfactant media $[41,42,47,108,109]$ that enables CPEs to function efficiently in the present of proteins [47]; see Figure 5. However, this factor may undermine the use of CPEs that have been bulk modified with lipophiles, such as stearic acid, for the detection of DA [110,111] because such species can be removed from the electrode surface following contact with brain tissue [42], although this point is still subject to debate [33]. 
The principal disadvantage of CPEs is their comparatively large size, and neurochemical studies have been limited to relatively large brain areas such as dorsal striatum [112-114], nucleus accumbens [114-116], cortical regions [117,118], pallidum [119] and hippocampus [114,118,120]. Other neurochemical analytes monitored by means of oxidation at implanted CPEs include: ascorbic acid [54,82,95,114,118,121-127], that may be linked to excitatory amino acid neurotransmission [120,128-134]; uric acid [87-89,93,94,97,118,125,135-137], the concentration of which appears to reflect the extent of tissue reaction to the implanted electrodes [86-89] (see Figure 4); 5hydroxyindoleacetic acid (5HIAA) the monoamine oxidase metabolite of the neuromodulator 5HT, using the smaller implantable CPEs (125- $\mu \mathrm{m}$ diameter; see Figure 4) [87]; and the reduction of molecular oxygen $[121,123,138-140]$ that reflects local cerebral blood flow under certain conditions [138].
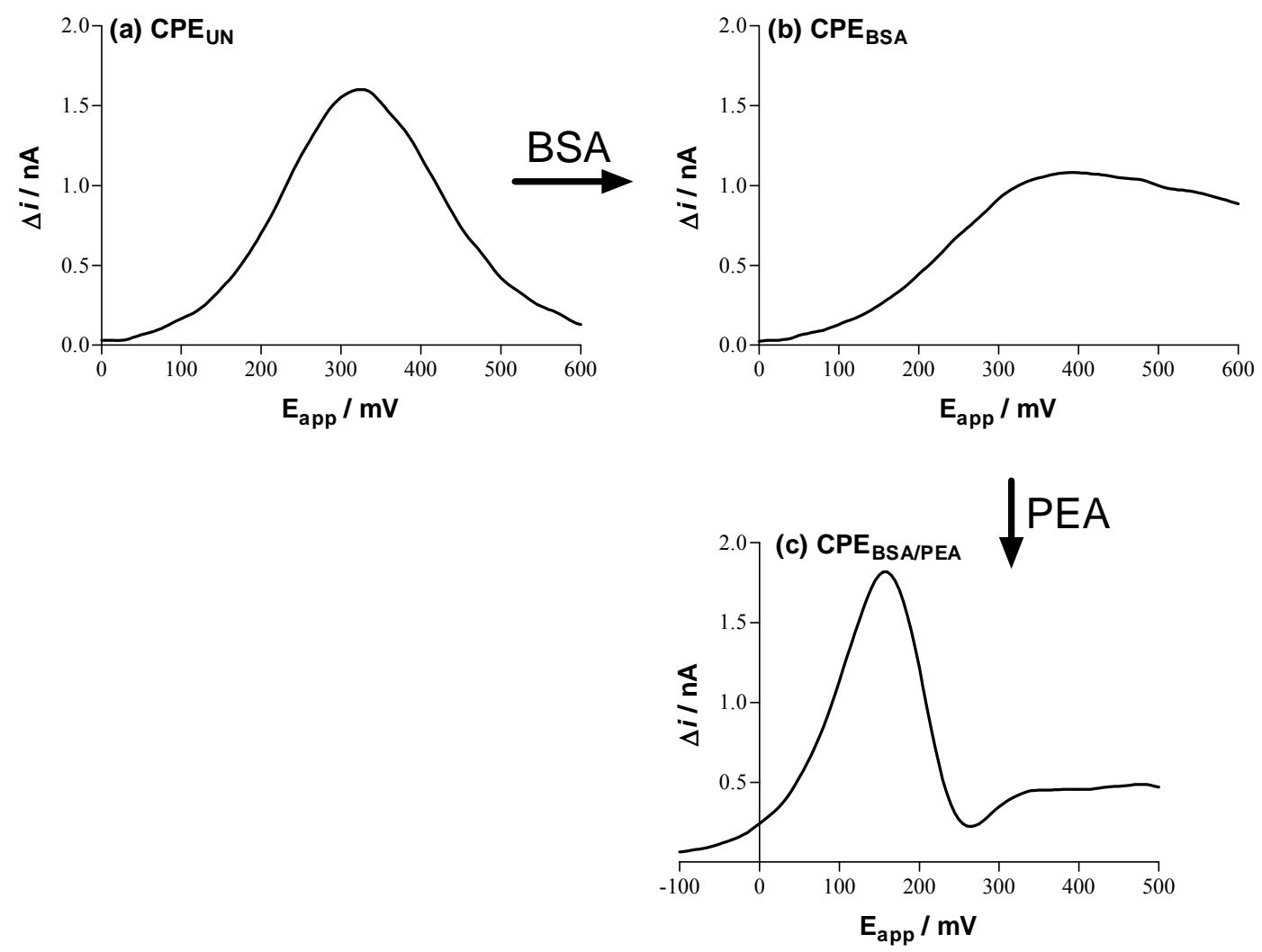

Figure 5. Differential staircase voltammograms recorded sequentially in vitro for $1 \mathrm{mM}$ ascorbate with a CPE in phosphate buffer (PBS, $\mathrm{pH}$ 7.4) containing various treatment media: (a) background electrolyte, PBS; (b) 10\% protein, bovine serum albumin (BSA), in PBS; and then (c) 10\% lipid, phosphatidylethanolamine (PEA), in PBS. The current scales are the same to compare the effects of treatment on electrode sensitivity. Although the start potential differs because of different peak potential values, the voltage range is the same in all three cases $(600 \mathrm{mV})$ so that peak width can be compared visually. Compare (c) with peak 1 in Figure 4. See Ref. [47] for more detailed data and discussion. 
The use of activated carbon fiber electrodes ( $\boldsymbol{a C F E s )}$ as an alternative to CPEs for IVV studies has been driven mainly by their small diameter (usually $<10 \mu \mathrm{m}$ ) and their ability to resolve ascorbate and catechol peaks for periods of a few hours in brain tissue, using pulse [141-143] or staircase [144] voltammetries. Clearly, the electro-oxidation of ascorbate and other species is more facile at aCFEs $[141,145]$ than at unmodified CPEs $[41,104]$ in neutral buffer. However, exposure to lipid-rich media in vitro, or to brain tissue in vivo, has opposite effects on the two electrode types: lipid-treated CPEs are much more responsive to ascorbate (Figure 5) than lipid-treated aCFEs [47]. These results provide an explanation for the loss of $\boldsymbol{a C F E}$ signal resolution after implantation in vivo, and also elucidate the mechanism whereby CPEs can be used over months in brain tissue (Figure 4), allowing long-term studies not possible with $\boldsymbol{a C F E s}$. The problem of loss of signal resolution after implantation of $\boldsymbol{a C F E s}$ in vivo has been addressed by the use of removable electrode systems that allow easy electrode replacement in the same animal [146-148], although it has been suggested that no more than three insertions should be carried out on account of tissue disruption [149].

A range of studies on the time-course of DA dynamics monitored in the ECF during behavior has been reported recently, using CFEs with either high-speed chronoamperometry [148,150] or fast cyclic voltammetry $[13,16,147]$. However, the ability to monitor brain DA metabolism continuously over periods of months in discrete brain areas is presently unique to CPEs, although the temporal resolution of the metabolite signal must be measured in minutes rather than seconds. Thus, the choice of technique for studying DA function will depend on the aims of the study. Here, for example, the stable HVA signal available with CPEs has been used to study long-term changes of DA turnover in response to drugs and behavioral manipulation.

\section{Pharmacological Studies}

The height of peak $3\left(h_{3}\right)$ recorded with chronically implanted CPEs (see Figure 4 ) has been used to study the effects of drugs on DA metabolism in different brain areas with a significant dopaminergic innervation [59,82,92,97,151-153]. Intraperitoneal (i.p.) administration of a DA synthesis inhibitor, $\alpha$-methyl-p-tyrosine (AMPT, $250 \mathrm{mg} / \mathrm{kg}$ ), caused a massive decrease in $\mathrm{h}_{3}$ associated with the loss of HVA from the ECF (see Figure 1) in frontal cortex, dorsal striatum and nucleus accumbens (94-98\%); indeed, this effect is part of the evidence used to establish the link between peak 3 and DA pathways [59,117]. Systemic administration of the DA receptor antagonist, haloperidol, that binds to most sub-types of DA receptors, led to substantial and sustained increase in ECF HVA in striatum and accumbens due to the blocking of the receptor-mediated negative feedback control of DA synthesis and release by this drug through both pre- and post-synaptic pathways. Despite the long-lasting effect of this dose of haloperidol $(0.5 \mathrm{mg} / \mathrm{kg}$ i.p., $\sim 12 \mathrm{~h})$, the CPEs were stable enough to monitor the return of HVA levels to baseline values (see Figure 6).

A summary of the effects of haloperidol and the non-specific DA receptor agonist, apomorphine, that activates the same negative feedback loops, on the HVA signal in the three brain areas is given in Figure 7. These, and other, data have been used to suggest that the strength of 
negative feedback is weaker in the frontal cortex compared with the two sub-cortical regions [117,154], and that this feedback regulation is also somewhat weaker in the accumbens (ventral striatum) compared with the dorsal striatum [117].

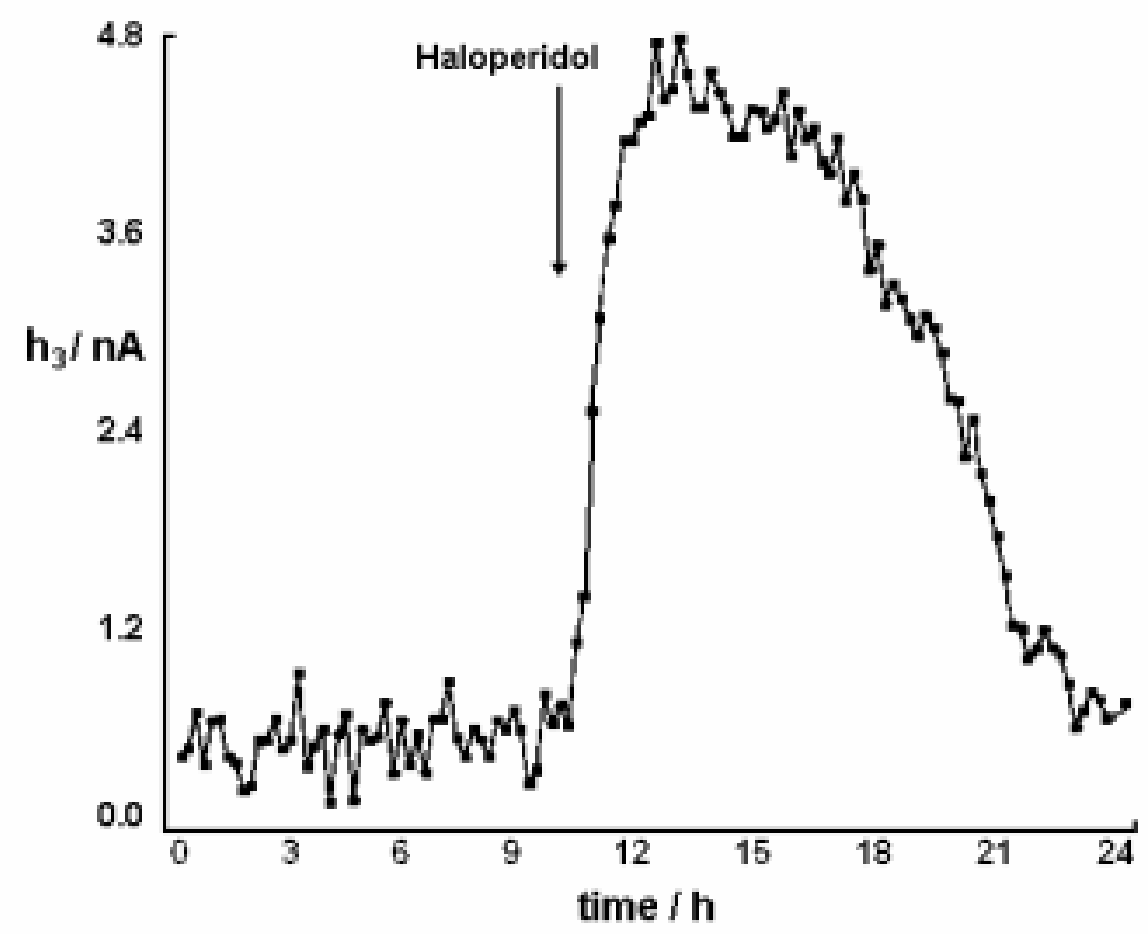

Figure 6. Time-course over $24 \mathrm{~h}$ of the effect of haloperidol $(0.5 \mathrm{mg} / \mathrm{kg}$ i.p. $)$ on the HVA signal (height of peak 3; see Figure 4) recorded at 12-min intervals in the dorsal striatum [59].
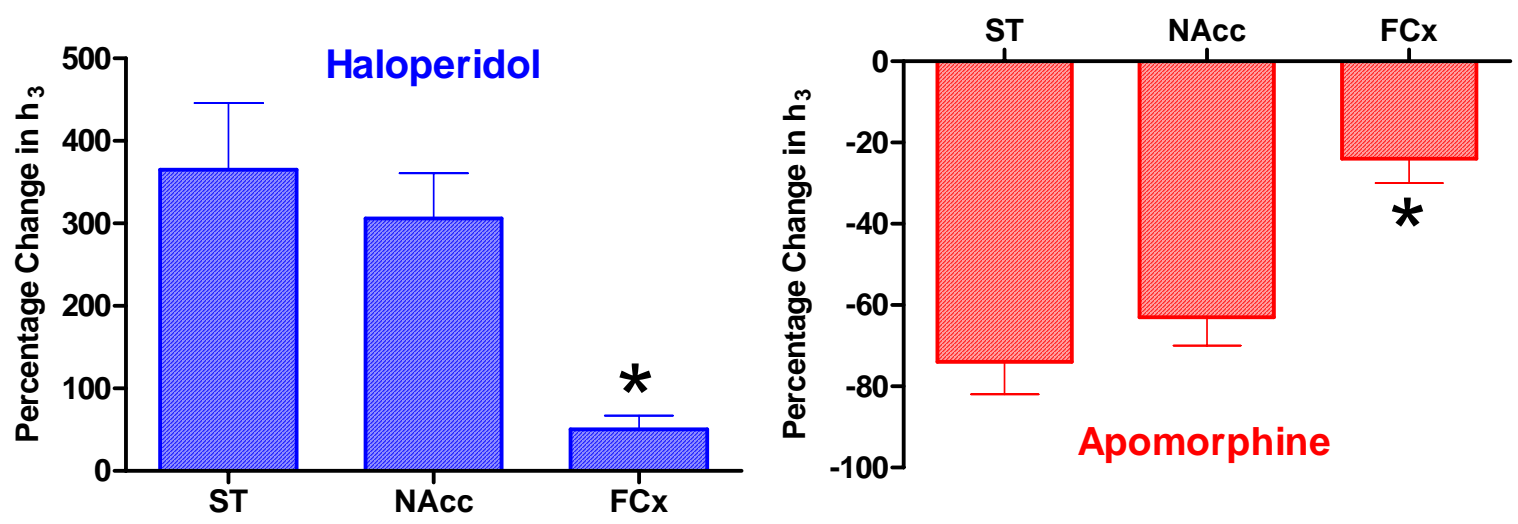

Figure 7. Mean \pm SEM for the maximum effects of haloperidol $(0.5 \mathrm{mg} / \mathrm{kg}$ i.p. $)$ and apomorphine (2 $\mathrm{mg} / \mathrm{kg}$ i.p.) on the height of peak 3 (see Figure 4) recorded in three brain regions, expressed as a percentage of the pre-injection value (see Figure 6 for sample time-course). The effect of haloperidol was similar in dorsal striatum $(\mathrm{ST}, \mathrm{n}=9$ ) and nucleus accumbens (NAcc, $\mathrm{n}=6$ ), but significantly smaller in frontal cortex $(\mathrm{FCx}, \mathrm{n}=6, * \mathrm{P}<0.05)$ compared with both $\mathrm{ST}$ and NAcc. The effect of apomorphine was also similar in ST $(n=7)$ and NAcc $(n=6)$, but significantly smaller in FCx $(n=4$, $* \mathrm{P}<0.05)$ compared with both sub-cortical areas [117]. 
More sophisticated studies on the long-term effects of receptor ligands on the HVA signals, recorded using CPEs in striatum and accumbens, have been carried out by Brose et al. [152,153]. In one investigation, that involved 11 days of continuous voltammetric recording [153], an anxiogenic $\beta$ carboline (N-methyl- $\beta$-carboline-3-carboxylate) was found to have different effects in these two forebrain regions. There was an initial depression of HVA levels in the accumbens on the day of the injection that returned to baseline the following day, but then increased on days 3-6 after administration before returning again to baseline levels. No effect was observed for striatal HVA. These results have been used to highlight the role of mesolimbic DA in the behavioral and therapeutic effects of benzodiazepines [152,153].

\section{Behavioral Studies}

The release of DA in sub-cortical brain areas, specifically the dorsal striatum [155] and nucleus accumbens [156] has long been recognized as an important factor in the expression of motor behaviors [157]. However, many of these early studies implicating neurotransmitters in specific behaviors involved major perturbations of the brain, such as lesioning identifiable pathways [12,158], infusion of drugs into individual brain areas [155,159], or post-mortem assays of brain tissue [160,161]. The development of in-vivo monitoring techniques, such as IVV and cerebral microdialysis [15,38,162-175] now allows detection of the release and metabolism of endogenous neurotransmitters during behavior.

Different forms of IVV can be categorized on the basis of the time resolution achieved for detecting changes in the concentration of species in the ECF. Fast techniques with resolutions of the order of seconds or less are chronoamperometry, fast cyclic voltammetry, differential pulse amperometry and constant potential amperometry [29,36,37,39,176,177], and these methods are generally used to detect stimulated changes in neurotransmitter overflow, although recent advances has allowed detection of non-stimulated DA release during behavior [147]. Slow techniques with time resolutions of the order of several minutes are linear sweep, staircase, differential pulse and differential normal pulse voltammetries at slow scan rates. The latter are usually used in studies of neurotransmitter metabolites, as well as ascorbic and uric acids [29,36,89,132]. The minimum interval between scans is limited not only by the sweep time but also by the time taken for the concentration of the electrolyzed species in the compartment around the implanted electrode tip to return to its unperturbed value by means of tortuous diffusion through the tissue matrix [46]. Although the HVA signal recorded using staircase voltammetry (see Figure 4) falls into the slower category, the stability of the CPEs allows long-term behavioral studies not possible with either other voltammetric methods or microdialysis.

Figure 8 shows an example of the parallel time-courses of DA metabolism in the striatum and simultaneously monitored motor activity levels over a 3-day period. Rats are nocturnal and show a significantly higher level of motor activity during the hours of darkness. Associated with this activity, striatal HVA levels are also increased. Moreover, the diurnal increase in HVA concentration in the ECF, expressed as the percentage change in $h_{3}$ during the hours of darkness compared with baseline 
lights-on values, were significantly higher in striatum $(52 \pm 5 \%, \mathrm{n}=14)$ and accumbens $(48 \pm 7 \%, \mathrm{n}=$ 14) compared with frontal cortex $(20 \pm 19 \%, n=9)$ where the increase itself was not statistically significant [117]. Correlation analyses have also been used to demonstrate the greater involvement of the nucleus accumbens in locomotion levels, whereas dorsal striatum may be more important in the expression of patterns of movement and posture [157,178,179].

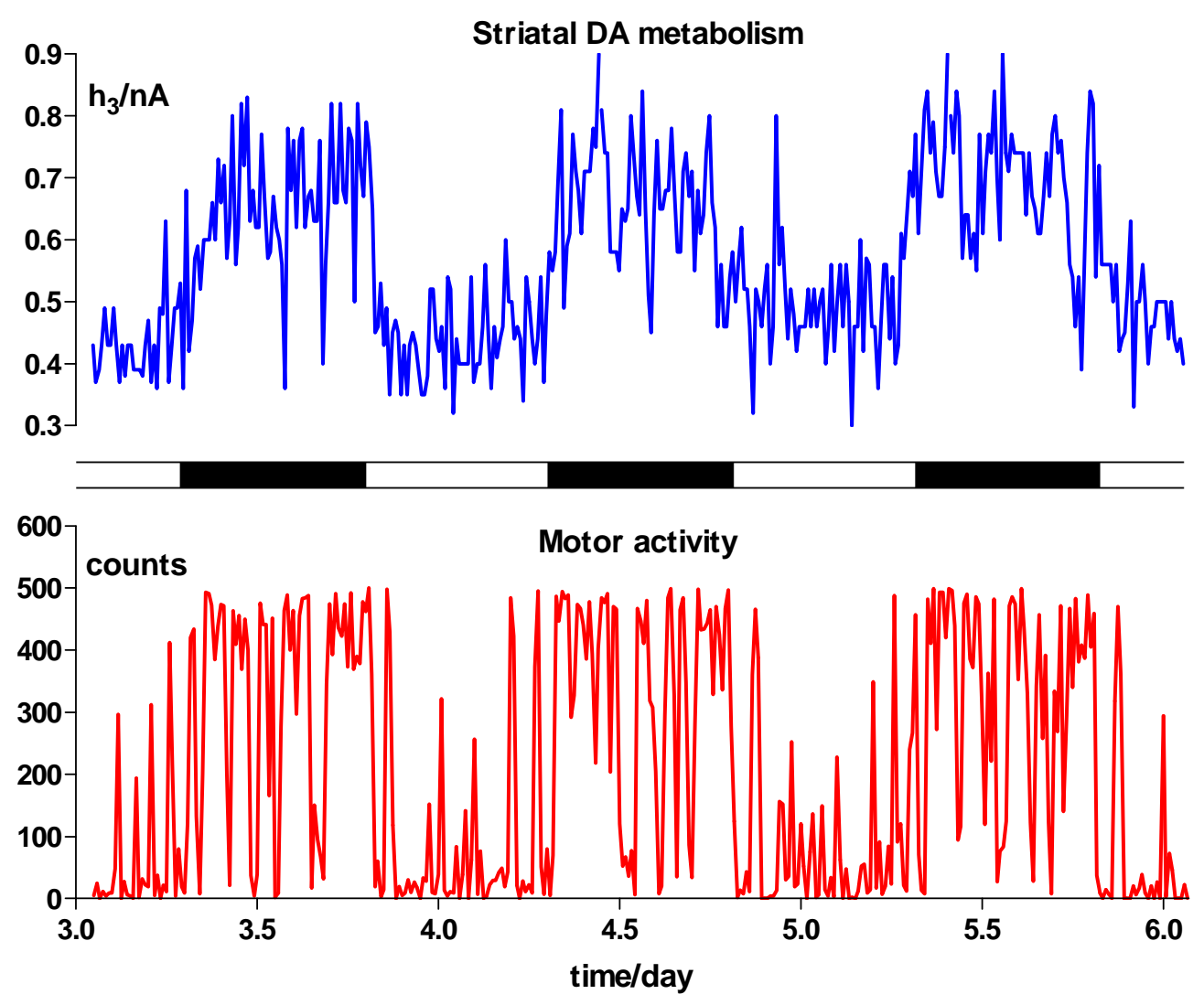

Figure 8. Time course over 3 days of changes in the HVA signal (peak 3, see Figure 4) recorded with a CPE in the striatum of a freely-moving rat at 12-min intervals (blue) and simultaneously monitored motor activity (red). Each day's recording started at $12.00 \mathrm{~h}$, with lights off from $20.00 \mathrm{~h}$ to $08.00 \mathrm{~h}$ as indicated by the light/dark band (center). The period shown corresponds to days 3 to 6 of a longer recording period, and is a demonstration of the stability of CPEs in brain tissue. These results reveal the tight correlation that normally exists between the diurnal pattern of spontaneous locomotion observed behaviorally and the activity of DA terminals in the striatum (both dorsal and ventral) [117].

In another study, during which the HVA signal was recorded continuously over a 2-week period [180], a very simple model of jet-lag was applied to the diurnal recordings illustrated in Figure 8. Reversal of the light-dark conditions on day 6 caused a breakdown in the correlations between diurnal motor activity levels and DA metabolism (HVA) that are normally observed in both dorsal and ventral striatum (see Figure 8). The correlation gradually became re-established over the following days, suggesting that DA neurotransmission, at least in the accumbens, might be involved in the 
development of symptoms associated with jet-lag. It is interesting to note that benzodiazepine receptor agonists are used to reduce sleep latency, increase total sleep time, and decrease awakenings in humans [181], and have also been shown to affect HVA levels recorded with CPEs in accumbens, but not striatum, in animal models [153].

Studies involving lever pressing for food reward have been used to explore the application of CPEs to investigate well defined experimental designs in psychology [92,135]. Increases in dopaminergic activity, reflected in the HVA signal, were observed in both dorsal striatum [92] and accumbens [135] following bouts of trained lever pressing. Furthermore, in individual subjects, both the behavioral response rates and the corresponding increases in peak 3 (see Figure 4) remained stable when studied periodically over a 3-month period [135]. These results represent another demonstration of the exceptional stability of CPEs implanted in the brain, and equally importantly, evidence that the initial surgery and the perturbations associated with chronic electrode implantation do not interfere unduly with relatively subtle behaviors recorded over periods of months.

\section{Conclusions}

Extensive characterization of the response of CPEs in vitro and in vivo has shown that peak 3 recorded with either staircase or linear sweep voltammetry in brain regions receiving a significant dopaminergic innervation is due to the oxidation of methylated metabolites of DA, that is almost exclusively HVA. The stability of CPE over months of recording provides a useful approach to investigating the long-term effects of drugs on DA activity in specific brain regions, as well as behavioral studies not possible with other in-vivo monitoring techniques.

\section{Acknowledgements}

Financial support from Science Foundation Ireland (Investigator Programme Grant 03/IN3/B376 and Basic Research Grant 04/BR/C0198) and University College Dublin is gratefully acknowledged.

\section{References}

1. Montague, P.R.; Hyman, S.E.; Cohen, J.D. Computational roles for dopamine in behavioural control. Nature 2004, 431, 760-767.

2. Pezze, M.A.; Feldon, J. Mesolimbic dopaminergic pathways in fear conditioning. Prog. Neurobiol. 2004, 74, 301-320.

3. Rye, D.B. The two faces of Eve - Dopamine's modulation of wakefulness and sleep. Neurology 2004, 63, S2-S7. 
4. Gluck, M.R.; Santana, L.A.; Granson, H.; Yahr, M.D. Novel dopamine releasing response of an anti-convulsant agent with possible anti-Parkinson's activity. J. Neural Trans. 2004, 111, 713724.

5. Cools, R.; Robbins, T.W. Chemistry of the adaptive mind. Phil. Trans. Roy. Soc. Lond. Ser. A Math. Phys. Engin. Sci. 2004, 362, 2871-2888.

6. Leng, A.; Feldon, J.; Ferger, B. Long-term social isolation and medial prefrontal cortex: dopaminergic and cholinergic neurotransmission. Pharmacol. Biochem. Behav. 2004, 77, 371 379.

7. Lynel, J.; Kelly, B.D.; O'Connor, W.T. Schizophrenia: a review of neuropharmacology. Irish J. Med. Sci. 2004, 173, 155-159.

8. Palsson, E.; Klamer, D.; Wass, C.; Archer, T.; Engel, J.A.; Svensson, L. The effects of phencyclidine on latent inhibition in taste aversion conditioning: differential effects of preexposure and conditioning. Behav. Brain Res. 2005, 157, 139-146.

9. Zhang, J.H.; Engel, J.A.; Soderpalm, B.; Svensson, L. Repeated administration of amphetamine induces sensitisation to its disruptive effect on prepulse inhibition in the rat. Psychopharmacology 1998, 135, 401-406.

10. Garris, P.A.; Kilpatrick, M.; Bunin, M.A.; Michael, D.; Walker, Q.D.; Wightman, R.M. Dissociation of dopamine release in the nucleus accumbens from intracranial self-stimulation. Nature 1999, 398, 67-69.

11. Reynolds, J.N.J.; Hyland, B.I.; Wickens, J.R. A cellular mechanism of reward-related learning. Nature 2001, 413, 67-70.

12. Antelman, S.M.; Szechtman, H.; Chin, P.; Fisher, A.E. Tail pinch-induced eating, gnawing and licking behavior in rats: dependence on the nigrostriatal dopamine system. Brain Res. 1975, 99, 319-337.

13. Roitman, M.F.; Stuber, G.D.; Phillips, P.E.M.; Wightman, R.M.; Carelli, R.M. Dopamine operates as a subsecond modulator of food seeking. J. Neurosci. 2004, 24, 1265-1271.

14. Ahlenius, S.; Carlsson, A.; Hillegaart, V. Region-selective activation of brain monoamine synthesis by sexual activity in the male rat. Eur. J. Pharmacol. 1987, 144, 77-82.

15. Mas, M. Neurobiological correlates of masculine sexual behavior. Neurosci. Biobehav. Rev. 1995, 19, 261-277.

16. Phillips, P.E.M.; Stuber, G.D.; Heien, M.L.A.V.; Wightman, R.M.; Carelli, R.M. Subsecond dopamine release promotes cocaine seeking. Nature 2003, 422, 614-618.

17. Ferguson, S.A.; Gough, B.J.; Cada, A.M. In vivo basal and amphetamine-induced striatal dopamine and metabolite levels are similar in the spontaneously hypertensive, Wistar-Kyoto and Sprague-Dawley male rats. Physiol. Behav. 2003, 80, 109-114. 
18. Sprague, J.E.; Everman, S.L.; Nichols, D.E. An integrated hypothesis for the serotonergic axonal loss induced by 3,4-methylenedioxymethamphetamine. Neurotoxicology 1998, 19, 427441.

19. Parkin, M.C.; Hopwood, S.E.; Strong, A.J.; Boutelle, M.G. Resolving dynamic changes in brain metabolism using biosensors and on-line microdialysis. Trends Anal. Chem. 2003, 22, 487-497.

20. Bungay, P.M.; Newton-Vinson, P.; Isele, W.; Garris, P.A.; Justice, J.B. Microdialysis of dopamine interpreted with quantitative model incorporating probe implantation trauma. $J$. Neurochem. 2003, 86, 932-946.

21. Crespi, F.; Croce, A.C.; Fiorani, S.; Masala, B.; Heidbreder, C.; Bottiroli, G. Autofluorescence spectrofluorometry of central nervous system (CNS) neuromediators. Lasers in Surgery and Medicine 2004, 34, 39-47.

22. Burmeister, J.J.; Palmer, M.; Gerhardt, G.A. Ceramic-based multisite microelectrode array for rapid choline measures in brain tissue. Anal. Chim. Acta 2003, 481, 65-74.

23. O'Neill, R.D.; Chang, S.C.; Lowry, J.P.; McNeil, C.J. Comparisons of platinum, gold, palladium and glassy carbon as electrode materials in the design of biosensors for glutamate. Biosensors Bioelectron. 2004, 19, 1521-1528.

24. Marsden, C.A.; Joseph, M.H.; Kruk, Z.L.; Maidment, N.T.; O'Neill, R.D.; Schenk, J.O.; Stamford, J.A. In vivo voltammetry - Present electrodes and methods. Neuroscience 1988, 25, 389-400.

25. Stamford, J.A. In vivo voltammetry - prospects for the next decade. Trends Neurosci. 1989, 12, 407-412.

26. Adams, R.N. In vivo electrochemical measurements in the CNS. Prog. Neurobiol. 1990, 35, 297-311.

27. Ewing, A.G.; Strein, T.G.; Yi, L. Analytical chemistry in microenvironments: Single nerve cells. Accounts Chem. Res. 1992, 25R, 440-447.

28. Kawagoe, K.T.; Zimmerman, J.B.; Wightman, R.M. Principles of voltammetry and microelectrode surface states. J. Neurosci. Methods 1993, 48, 225-240.

29. O'Neill, R.D. Microvoltammetric techniques and sensors for monitoring neurochemical dynamics in vivo - a review. Analyst 1994, 119, 767-779.

30. Boulton, A.A., Baker, G.B., and Adams, R.N. Voltammetric Methods in Brain Systems, Humana Press, New Jersey, 1995.

31. Kruk, Z.L.; O'Connor, J.J. Fast electrochemical studies in isolated tissues. Trends Pharmacol. Sci. 1995, 16, 145-149. 
32. Pantano, P.; Kuhr, W.G. Enzyme-modified microelectrodes for in vivo neurochemical measurements. Electroanalysis 1995, 7, 405-416.

33. Blaha, C.D.; Phillips, A.G. A critical assessment of electrochemical procedures applied to the measurement of dopamine and its metabolites during drug-induced and species-typical behaviours. Behav. Pharmacol. 1996, 7, 675-708.

34. Stamford, J.A.; Justice, J.B. Probing brain chemistry. Anal. Chem. 1996, 68, A359-A363.

35. O'Neill, R.D. Neurochemical analysis using sensors. In Biosensors in the Body: Continuous In Vivo Monitoring; Fraser, D.M. (Ed.), John Wiley \& Sons, Chichester, 1997; pp. 171-196.

36. O'Neill, R.D.; Lowry, J.P.; Mas, M. Monitoring brain chemistry in vivo: voltammetric techniques, sensors and behavioral applications. Crit. Rev. Neurobiol. 1998, 12, 69-127.

37. Michael, D.J.; Wightman, R.M. Electrochemical monitoring of biogenic amine neurotransmission in real time. J. Pharmaceut. Biomed. Anal. 1999, 19, 33-46.

38. Hutchinson, P.J.; O'Connell, M.T.; Kirkpatrick, P.J.; Pickard, J.D. How can we measure substrate, metabolite and neurotransmitter concentrations in the human brain? Physiol. Meas. 2002, 23, R75-R109.

39. Troyer, K.P.; Heien, M.L.A.V.; Venton, B.J.; Wightman, R.M. Neurochemistry and electroanalytical probes. Curr. Opin. Chem. Biol. 2002, 6, 696-703.

40. O'Neill, R.D. Sensor-tissue interactions in neurochemical analysis with carbon paste electrodes in vivo. Analyst 1993, 118, 433-438.

41. Ormonde, D.E.; O'Neill, R.D. The oxidation of ascorbic acid at carbon paste electrodes. Modified response following contact with surfactant, lipid and brain tissue. J. Electroanal. Chem. 1990, 279, 109-121.

42. Lyne, P.D.; O'Neill, R.D. Stearate-modified carbon paste electrodes for detecting dopamine in vivo: decrease in selectivity caused by lipids and other surface-active agents. Anal. Chem. 1990, $62,2347-2351$.

43. Cheng, H.Y.; Schenk, J.; Huff, R.; Adams, R.N. In vivo electrochemistry: behaviour of micro electrodes in brain tissue. J. Electroanal. Chem. 1979, 100, 23-31.

44. Dayton, M.A.; Ewing, A.G.; Wightman, R.M. Diffusion processes measured at microvoltammetric electrodes in brain tissue. J. Electroanal. Chem. 1983, 146, 189-200.

45. Amatore, C.; Kelly, R.S.; Kristensen, E.W.; Kuhr, W.G.; Wightman, R.M. Effects of restricted diffusion at ultramicroelectrodes in brain tissue. The pool model: theory and experiment for chronoamperometry. J. Electroanal. Chem. 1986, 213, 31-42.

46. Nicholson, C.; Sykova, E. Extracellular space structure revealed by diffusion analysis. Trends Neurosci. 1998, 21, 207-215. 
47. Kane, D.A.; O'Neill, R.D. Major differences in the behaviour of carbon paste and carbon fibre electrodes in a protein-lipid matrix: implications for voltammetry in vivo. Analyst 1998, 123, 2899-2903.

48. Wiedemann, D.J.; Basse-Tomusk, A.; Wilson, R.L.; Rebec, G.V.; Wightman, R.M. Interference by DOPAC and ascorbate during attempts to measure drug-induced changes in neostriatal dopamine with Nafion-coated, carbon-fiber electrodes. J. Neurosci. Methods 1990, $35,9-18$.

49. Khan, A.S.; Michael, A.C. Invasive consequences of using micro-electrodes and microdialysis probes in the brain. Trends Anal. Chem. 2003, 22, 503-508.

50. Phillips, P.E.M.; Wightman, R.M. Critical guidelines for validation of the selectivity of in-vivo chemical microsensors. Trends Anal. Chem. 2003, 22, 509-514.

51. Sabatini, B.L.; Regehr, W.G. Timing of neurotransmission at fast synapses in the mammalian brain. Nature 1996, 384, 170-172.

52. Meiergerd, S.M.; Schenk, J.O. Striatal transporter for dopamine: Catechol structure-activity studies and susceptibility to chemical modification. J. Neurochem. 1994, 62, 998-1008.

53. Vulto, A.G.; Westenberg, H.G.M.; Meijer, L.B.A.; Versteeg, D.H.G. The dopamine metabolite 3-methoxytyramine is not a suitable indicator of dopamine release in the rat brain. $J$. Neurochem. 1986, 47, 1387-1393.

54. Kissinger, P.T.; Hart, J.B.; Adams, R.N. Voltammetry in brain tissue - a new neurophysiological measurement. Brain Res. 1973, 55, 209-213.

55. Wu, Q.; Reith, M.E.A.; Wightman, R.M.; Kawagoe, K.T.; Garris, P.A. Determination of release and uptake parameters from electrically evoked dopamine dynamics measured by realtime voltammetry. J. Neurosci. Methods 2001, 112, 119-133.

56. Garris, P.A.; Budygin, E.A.; Phillips, P.E.M.; Venton, B.J.; Robinson, D.L.; Bergstrom, B.P.; Rebec, G.V.; Wightman, R.M. A role for presynaptic mechanisms in the actions of nomifensine and haloperidol. Neuroscience 2003, 118, 819-829.

57. Ottersen, O.P.; Landsend, A.S. Organization of glutamate receptors at the synapse. Eur. J. Neurosci. 1997, 9, 2219-2224.

58. Kullmann, D.M.; Asztely, F. Extrasynaptic glutamate spillover in the hippocampus: evidence and implications. Trends Neurosci. 1998, 21, 8-14.

59. O'Neill, R.D.; Fillenz, M. Detection of homovanillic acid in vivo using microcomputercontrolled voltammetry: simultaneous monitoring of rat motor activity and striatal dopamine release. Neuroscience 1985, 14, 753-763.

60. Kalen, P.; Strecker, R.E.; Rosengren, E.; Bjorklund, A. Endogenous release of neuronal serotonin and 5-hydroxyindoleacetic acid in the caudate-putamen of the rat as revealed by 
intracerebral dialysis coupled to high performance liquid chromatography with fluorimetric detection. J. Neurochem. 1988, 51, 1422-1435.

61. Zetterstrom, T.; Sharp, T.; Collin, A.K.; Ungerstedt, U. In vivo measurement of extracellular dopamine and DOPAC in rat striatum after various dopamine-releasing drugs; implications for the origin of extracellular DOPAC. Eur. J. Pharmacol. 1988, 148, 327-334.

62. Adams, R.N. Carbon paste electrodes. Anal. Chem. 1958, 30, 1576.

63. Kulys, J.; Gorton, L.; Dominguez, E.; Emneus, J.; Jarskog, H. Electrochemical characterization of carbon pastes modified with proteins and polycations. J. Electroanal. Chem. 1994, 372, 4955 .

64. Kalcher, K. Chemically modified carbon paste electrodes in voltammetric analysis. Electroanalysis 1990, 2, 419-433.

65. Svancara, I.; Vytras, K.I.; Barek, J.; Zima, J. Carbon paste electrodes in modern electroanalysis. Crit. Rev. Anal. Chem. 2001, 31, 311-345.

66. Tomcik, P.; Banks, C.E.; Davies, T.J.; Compton, R.G. A self-catalytic carbon paste electrode for the detection of vitamin B-12. Anal. Chem. 2004, 76, 161-165.

67. Wang, J.; Chen, L.; Liu, J. Critical comparison of metallized and mediator-based carbon paste glucose biosensors. Electroanalysis 1997, 9, 298-301.

68. Zima, J.; Barek, J.; Muck, A. Monitoring of environmentally and biologically important organic substances at carbon paste electrodes. Rev. Chim. 2004, 55, 657-661.

69. Hanrahan, G.; Patil, D.G.; Wang, J. Electrochemical sensors for environmental monitoring: design, development and applications. J. Environ. Monit. 2004, 6, 657-664.

70. El Maali, N.A. Voltammetric analysis of drugs. Bioelectrochemistry 2004, 64, 99-107.

71. Radi, A.; Wassel, A.A.; El Ries, M.A. Adsorptive behaviour and voltammetric analysis of propranolol at carbon paste electrode. Chem. Anal. 2004, 49, 51-58.

72. Farghaly, O.A.; Mohamed, N.A.L. Voltammetric determination of azithromycin at the carbon paste electrode. Talanta 2004, 62, 531-538.

73. Li, J.N.; Liu, S.M.; Mao, X.; Gao, P.; Yan, Z.H. Trace determination of rare earths by adsorption voltammetry at a carbon paste electrode. J. Electroanal. Chem. 2004, 561, 137-142.

74. Ferancova, A.; Korgova, E.; Labuda, J.; Zima, J.; Barek, J. Cyclodextrin modified carbon paste based electrodes as sensors for the determination of carcinogenic polycyclic aromatic amines. Electroanalysis 2002, 14, 1668-1673.

75. Wang, J.; Zhang, X.J.; Prakash, M. Glucose microsensors based on carbon paste enzyme electrodes modified with cupric hexacyanoferrate. Anal. Chim. Acta 1999, 395, 11-16. 
76. Kulys, J. The carbon paste electrode encrusted with a microreactor as glucose biosensor. Biosens. Bioelectron. 1999, 14, 473-479.

77. Miscoria, S.A.; Barrera, G.D.; Rivas, G.A. Analytical performance of a glucose biosensor prepared by immobilization of glucose oxidase and different metals into a carbon paste electrode. Electroanalysis 2002, 14, 981-987.

78. Vidal, J.C.; Garcia, E.; Mendez, S.; Yarnoz, P.; Castillo, J.R. Three approaches to the development of selective bilayer amperometric biosensors for glucose by in situ electropolymerization. Analyst 1999, 124, 319-324.

79. Rajendran, V.; Csoregi, E.; Okamoto, Y.; Gorton, L. Amperometric peroxide sensor based on horseradish peroxidase and toluidine blue o-acrylamide polymer in carbon paste. Anal. Chim. Acta 1998, 373, 241-251.

80. Diego, E.; Agui, L.; Gonzalez-Cortes, A.; Yanezsedeno, P.; Pingarron, J.M.; Kauffmann, J.M. Critical comparison of paraffin carbon paste and graphite-poly(tetrafluorethylene) composite electrodes concerning the electroanalytical behavior of various antioxidants of different hydrophobicity. Electroanalysis 1998, 10, 33-38.

81. Brainina, K.Z.; Malakhova, N.A.; Stojko, N.Y. Stripping voltammetry in environmental and food analysis. Fresenius J. Anal. Chem. 2000, 368, 307-325.

82. O'Neill, R.D.; Grunewald, R.A.; Fillenz, M.; Albery, W.J. Linear sweep voltammetry with carbon paste electrodes in the rat striatum. Neuroscience 1982, 7, 1945-1954.

83. Lane, R.F.; Hubbard, A.T.; Blaha, C.D. Application of semi-derivative electroanalysis to studies of neurotransmitters in the central nervous system. J. Electroanal. Chem. 1979, 95, 117-122.

84. O'Neill, R.D.; Fillenz, M.; Albery, W.J.; Goddard, N.J. The monitoring of ascorbate and monoamine transmitter metabolites in the striatum of unanaesthetised rats using microprocessor-based voltammetry. Neuroscience 1983, 9, 87-93.

85. O'Neill, R.D.; Fillenz, M.; Albery, W.J. The development of linear sweep voltammetry with carbon paste electrodes in vivo. J. Neurosci. Methods 1983, 8, 263-273.

86. Duff, A.; O'Neill, R.D. The importance of probe size in monitoring neurochemical signals in behaving animals. Behav. Brain Res. 1995, 71, 41-42.

87. Duff, A.; O'Neill, R.D. Effect of probe size on the concentration of brain extracellular uric acid monitored with carbon paste electrodes. J. Neurochem. 1994, 62, 1496-1502.

88. O'Neill, R.D.; Gonzalez-Mora, J.L.; Boutelle, M.G.; Ormonde, D.E.; Lowry, J.P.; Duff, A.; Fumero, B.; Fillenz, M.; Mas, M. Anomalously high concentrations of brain extracellular uric acid detected with chronically implanted probes: implications for in vivo sampling techniques. J. Neurochem. 1991, 57, 22-29. 
89. O'Neill, R.D.; Lowry, J.P. On the significance of brain extracellular uric acid detected with invivo monitoring techniques: A review. Behav. Brain Res. 1995, 71, 33-49.

90. Cheng, H.Y. Compartment model for chronoamperometric measurement in vivo. J. Electroanal. Chem. 1982, 135, 145-151.

91. Albery, W.J.; Fillenz, M.; O'Neill, R.D. The compartment model for chronically implanted voltammetric electrodes in the rat brain. Neurosci. Lett. 1983, 38, 175-180.

92. Joseph, M.H.; Hodges, H.; Gray, J.A. Lever pressing for food reward and in vivo voltammetry: evidence for increases in extracellular homovanillic acid, the dopamine metabolite, and uric acid in the rat caudate nucleus. Neuroscience 1989, 32, 195-201.

93. O'Neill, R.D.; Fillenz, M.; Grunewald, R.A.; Bloomfield, M.R.; Albery, W.J.; Jamieson, C.M.; Williams, J.H.; Gray, J.A. Voltammetric carbon paste electrodes monitor uric acid and not 5HIAA at the 5-hydroxyindole potential in the rat brain. Neurosci. Lett. 1984, 45, 39-46.

94. Mueller, K.; Palmour, R.; Andrews, C.D.; Knott, P.J. In vivo voltammetric evidence of production of uric acid by rat caudate. Brain Res. 1985, 335, 231-235.

95. Boutelle, M.G.; Svensson, L.; Fillenz, M. Rapid changes in striatal ascorbate in response to tail-pinch monitored by constant potential voltammetry. Neuroscience 1989, 30, 11-17.

96. O'Neill, R.D.; Grunewald, R.A.; Fillenz, M.; Albery, W.J. The effect of unilateral cortical lesions on the circadian changes in rat striatal ascorbate and homovanillic acid levels measured in vivo using voltammetry. Neurosci. Lett. 1983, 42, 105-110.

97. Joseph, M.H.; Young, A.M.J. Pharmacological evidence, using in vivo dialysis, that substances additional to ascorbic acid, uric acid and homovanillic acid contribute to the voltammetric signals obtained in unrestrained rats from chronically implanted carbon paste electrodes. $J$. Neurosci. Methods 1991, 36, 209-218.

98. Slivka, A.; Brannan, T.S.; Weinberger, J.; Knott, P.J.; Cohen, G. Increase in extracellular dopamine in the striatum during cerebral ischemia: a study utilizing cerebral microdialysis. $J$. Neurochem. 1988, 50, 1714-1718.

99. Vulto, A.G.; Sharp, T.; Ungerstedt, U.; Versteeg, D.H.G. Rapid postmortem increase in extracellular dopamine in the rat brain as assessed by brain microdialysis. J. Neurochem. 1988, $51,746-749$.

100. Gonzalez-Mora, J.L.; Maidment, N.T.; Guadalupe, T.; Mas, M. Post-mortem dopamine dynamics assessed by voltammetry and microdialysis. Brain Res. Bull. 1989, 23, 323-327.

101. Kawagoe, K.T.; Garris, P.A.; Wiedemann, D.J.; Wightman, R.M. Regulation of transient dopamine concentration gradients in the microenvironment surrounding nerve terminals in the rat striatum. Neuroscience 1992, 51, 55-64. 
102. Gonzalez-Mora, J.L.; Sanchez-Bruno, J.A.; Mas, M. Concurrent on-line analysis of striatal ascorbate, dopamine and dihydroxyphenylacetic acid concentrations by in vivo voltammetry. Neurosci. Lett. 1988, 86, 61-66.

103. Church, W.H.; Justice, J.B., Jr. Rapid sampling and determination of extracellular dopamine in vivo. Anal. Chem. 1987, 59, 712-716.

104. Rice, M.E.; Galus, Z.; Adams, R.N. Graphite paste electrodes. Effects of paste composition and surface states on electron transfer rates. J. Electroanal. Chem. 1983, 143, 89-102.

105. Lyne, P.D.; O'Neill, R.D. Selectivity of stearate-modified carbon paste electrodes for dopamine and ascorbic acid. Anal. Chem. 1989, 61, 2323-2324.

106. Blaha, C.D.; Jung, M.E. Electrochemical evaluation of stearate-modified graphite paste electrode: selective detection of dopamine is maintained after exposure to brain tissue. $J$. Electroanal. Chem. 1991, 310, 317-334.

107. Ormonde, D.E.; O'Neill, R.D. Altered response of carbon paste electrodes after contact with brain tissue. Implications for modified electrode use in vivo. J. Electroanal. Chem. 1989, 261, 463-469.

108. Albahadily, F.N.; Mottola, H.A. Improved rsponse of carbon-paste electrodes for electrochemical detection in flow systems by pretreatment with surfactants. Anal. Chem. 1987, 59, 958-962.

109. Digua, K.; Kauffmann, J.M.; Delplancke, J.L. Surfactant modified carbon paste electrode. 1. Electrochemical and microscopic characterization. Electroanalysis 1994, 6, 451-458.

110. Blaha, C.D.; Lane, R.F. Chemically modified electrode for in vivo monitoring of brain catecholamines. Brain Res. Bull. 1983, 10, 861-864.

111. Broderick, P.A. State-of-the-art microelectrodes for in vivo voltammetry. Electroanalysis 1990, 2, 241-251.

112. Clemens, J.A.; Phebus, L.A. Changes in brain chemistry produced by dopaminergic agents: in vivo electrochemical monitoring reveals opposite changes in anaesthetized vs unanaesthetized rats. Brain Res. 1983, 267, 183-186.

113. Mueller, K.; Haskett, C. Effects of haloperidol on amphetamine-induced increases in ascorbic acid and uric acid as determined by voltammetry in vivo. Pharmacol. Biochem. Behav. 1987, 27, 231-234.

114. Boutelle, M.G.; Svensson, L.; Fillenz, M. Effect of diazepam on behaviour and associated changes in ascorbate concentration in rat brain areas: striatum, n. accumbens and hippocampus. Psychopharmacology 1990, 100, 230-236.

115. Mueller, K. Repeated administration of high doses of amphetamine increases release of ascorbic acid in caudate but not nucleus accumbens. Brain Res. 1989, 494, 30-35. 
116. Brazell, M.P.; Mitchell, S.N.; Joseph, M.H.; Gray, J.A. Acute administration of nicotine increases the in vivo extracellular levels of dopamine, 3,4-dihydroxyphenylacetic acid and ascorbic acid preferentially in the nucleus accumbens of the rat: Comparison with caudateputamen. Neuropharmacology 1990, 29, 1177-1185.

117. O'Neill, R.D.; Fillenz, M. Simultaneous monitoring of dopamine release in rat frontal cortex, nucleus accumbens and striatum: effect of drugs, circadian changes and correlations with motor activity. Neuroscience 1985, 16, 49-55.

118. Mueller, K.; Kunko, P.M. The effects of amphetamine and pilocarpine on the release of ascorbic and uric acid in several rat brain areas. Pharmacol. Biochem. Behav. 1990, 35, 871876.

119. Haskett, C.; Mueller, K. The effects of serotonin depletion on the voltammetric response to amphetamine. Pharmacol. Biochem. Behav. 1987, 28, 381-384.

120. O'Neill, R.D.; Fillenz, M.; Sundstrom, L.; Rawlins, J.N.P. Voltammetrically monitored brain ascorbate as an index of excitatory amino acid release in the unrestrained rat. Neurosci. Lett. 1984, 52, 227-233.

121. Lowry, J.P.; Miele, M.; O'Neill, R.D.; Boutelle, M.G.; Fillenz, M. An amperometric glucoseoxidase/poly(o-phenylenediamine) biosensor for monitoring brain extracellular glucose: in vivo characterisation in the striatum of freely-moving rats. J. Neurosci. Methods 1998, 79, 65-74.

122. Miele, M.; Fillenz, M. Changes in extracellular brain ascorbate in rat striatum in response to administration of non-volatile anaesthetic agents. Br. J. Anaesth. 1997, 78, 588-590.

123. Lowry, J.P.; Boutelle, M.G.; O'Neill, R.D.; Fillenz, M. Characterization of carbon paste electrodes in vitro for simultaneous amperometric measurement of changes in oxygen and ascorbic acid concentrations in vivo. Analyst 1996, 121, 761-766.

124. Miele, M.; Fillenz, M. In vivo determination of extracellular brain ascorbate. J. Neurosci. Methods 1996, 70, 15-19.

125. Mueller, K. The effects of haloperidol and amphetamine on ascorbic acid and uric acid in caudate and nucleus accumbens of rats as measured by voltammetry in vivo. Life Sci. 1990, 47, 735-742.

126. Brose, N.; O'Neill, R.D.; Boutelle, M.G.; Fillenz, M. The effects of anxiolytic and anxiogenic benzodiazepine receptor ligands on motor activity and levels of ascorbic acid in the nucleus accumbens and striatum of the rat. Neuropharmacology 1989, 28, 509-514.

127. O'Neill, R.D.; Fillenz, M. Circadian changes in extracellular ascorbate in rat cortex, accumbens, striatum and hippocampus: correlations with motor activity. Neurosci. Lett. 1985, 60, 331-336.

128. Rebec, G.V.; Witowski, S.R.; Sandstrom, M.I.; Rostand, R.D.; Kennedy, R.T. Extracellular ascorbate modulates cortically evoked glutamate dynamics in rat striatum. Neurosci. Lett. 2005, 378, 166-170. 
129. Song, J.H.; Shin, S.H.; Chung, M.I. Effects of glutamate on dehydroascorbate uptake and its enhanced vulnerability to the peroxidation in cerebral cortical slices. Exp. Mol. Med. 2002, 34, 419-425.

130. Liu, J.; Wu, C.F.; Zhang, H.L.; Li, C.L. Involvement of the corticostriatal glutamatergic pathway in ethanol-induced ascorbic acid release in rat striatum. Addict. Biol. 1999, 4, 273-281.

131. Enrico, P.; Mura, M.A.; Esposito, G.; Serra, P.; Migheli, R.; De Natale, G.; Desole, M.S.; Miele, M.; Miele, E. Effect of naloxone on morphine-induced changes in striatal dopamine metabolism and glutamate, ascorbic acid and uric acid release in freely moving rats. Brain Res. 1998, 797, 94-102.

132. O'Neill, R.D. The measurement of brain ascorbate in vivo and its link with excitatory amino acid neurotransmission. In Voltammetric Methods in Brain Systems; Boulton, A.A.; Baker, G.B.; Adams, R.N. (Eds.), Humana Press, New Jersey, 1995; pp. 221-268.

133. Rebec, G.V.; Pierce, R.C. A vitamin as neuromodulator: Ascorbate release into the extracellular fluid of the brain regulates dopaminergic and glutamatergic transmission. Prog. Neurobiol. 1994, 43, 537-565.

134. Grunewald, R.A. Ascorbic acid in the brain. Brain Res. Rev. 1993, 18, 123-133.

135. Joseph, M.H.; Hodges, H. Lever pressing for food reward and changes in dopamine turnover and uric acid in rat caudate and nucleus accumbens studied chronically by in vivo voltammetry. J. Neurosci. Methods 1990, 34, 143-149.

136. Joseph, M.H. Lever pressing for food reward and changes in dopamine turnover and uric acid in rat caudate and $n$. accumbens studied chronically by in vivo voltammetry. J. Neurosci. Methods 1989, 29, 276.

137. Mueller, K. Voltammetric evidence in vivo of cholinergic modulation of extracellular ascorbic acid and uric acid in rat striatum. Brain Res. 1987, 408, 313-316.

138. Lowry, J.P.; Boutelle, M.G.; Fillenz, M. Measurement of brain tissue oxygen at a carbon paste electrode can serve as an index of increases in regional cerebral blood flow. J. Neurosci. Methods 1997, 71, 177-182.

139. Dixon, B.M.; Lowry, J.P.; O'Neill, R.D. Characterization in vitro and in vivo of the oxygen dependence of an enzyme/polymer biosensor for monitoring brain glucose. J. Neurosci. Methods 2002, 119, 135-142.

140. Lowry, J.P.; Fillenz, M. Real-time monitoring of brain energy metabolism in vivo using microelectrochemical sensors: the effects of anesthesia. Bioelectrochemistry 2001, 54, 39-47.

141. Gonon, F.; Buda, M.; Cespuglio, R.; Jouvet, M.; Pujol, J.F. In vivo electrical detection of catechols in the rat neostriatum: dopamine or DOPAC? Nature 1980, 286, 902-904. 
142. Gonon, F.; Buda, M.; Cespuglio, R.; Jouvet, M.; Pujol, J.F. Voltammetry in the striatum of chronic freely moving rats: detection of catechols and ascorbic acid. Brain Res. 1981, 223, 6980 .

143. Marcenac, F.; Gonon, F. Fast in vivo monitoring of dopamine release in the rat brain with differential pulse amperometry. Anal. Chem. 1985, 57, 1778-1779.

144. Oh, C.; Gardiner, T.W.; Rebec, G.V. Blockade of both D1- and D2-dopamine receptors inhibits amphetamine-induced ascorbate release in the neostriatum. Brain Res. 1989, 480, 184-189.

145. Cahill, P.S.; Wightman, R.M. Simultaneous amperometric measurement of ascorbate and catecholamine secretion from individual bovine adrenal medullary cells. Anal. Chem. 1995, 67, 2599-2605.

146. Mas, M.; Gonzalez-Mora, J.L.; Louilot, A.; Sole, C.; Guadalupe, T. Increased dopamine release in the nucleus accumbens of copulating male rats as evidenced by in vivo voltammetry. Neurosci. Lett. 1990, 110, 303-308.

147. Venton, B.J.; Wightman, R.M. Psychoanalytical electrochemistry: Dopamine and behavior. Anal. Chem. 2003, 75, 414A-421A.

148. Yavich, L.; Tiihonen, J. In vivo voltammetry with removable carbon fibre electrodes in freelymoving mice: dopamine release during intracranial self-stimulation. J. Neurosci. Methods 2000, $104,55-63$.

149. Rebec, G.V.; Langley, P.E.; Pierce, R.C.; Wang, Z.; Heidenreich, B.A. A simple micromanipulator for multiple uses in freely moving rats: Electrophysiology, voltammetry, and simultaneous intracerebral infusions. J. Neurosci. Methods 1993, 47, 53-59.

150. Yavich, L.; Tiihonen, J. Patterns of dopamine overflow in mouse nucleus accumbens during intracranial self-stimulation. Neurosci. Lett. 2000, 293, 41-44.

151. Lane, R.F.; Hubbard, A.T.; Blaha, C.D. Brain dopaminergic neurons: in vivo electrochemical information concerning storage, metabolism and release processes. Bioelectrochem. Bioenerg. 1978, 5, 504-525.

152. Brose, N.; O'Neill, R.D.; Boutelle, M.G.; Anderson, S.M.P.; Fillenz, M. Effects of an anxiogenic benzodiazepine receptor ligand on rat motor activity and dopamine release in nucleus accumbens and striatum. J. Neurosci. 1987, 7, 2917-2926.

153. Brose, N.; O'Neill, R.D.; Boutelle, M.G.; Fillenz, M. Dopamine in the basal ganglia and benzodiazepine-induced sedation. Neuropharmacology 1988, 27, 589-595.

154. Fillenz, M.; O'Neill, R.D. Differences in feed-back regulation of dopamine release in the striatum and frontal cortex in the rat. J. Physiol. (London) 1983, 349, 11P.

155. Ungerstedt, U.; Butcher, L.L.; Butcher, S.G.; Anden, N.E.; Fuxe, K. Direct chemical stimulation of dopaminergic mechanisms in the neostriatum of the rat. Brain Res. 1969, 14, 461-471. 
156. Kelly, P.H.; Seviour, P.W.; Iversen, S.D. Amphetamine and apomorphine responses in the rat following 6OHDA lesions of the nucleus accumbens septi and corpus striatum. Brain Res. 1975, 94, 507-522.

157. Costall, B.; Naylor, R.J.; Nohria, V. Hyperactivity response to apomorphine and amphetamine in the mouse: the importance of the nucleus accumbens and caudate-putamen. J. Pharm. Pharmacol. 1979, 31, 259-261.

158. Iversen, S.D.; Wilkinson, S.; Simpson, B. Enhanced amphetamine responses after frontal cortex lesions in the rat. Eur. J. Pharmacol. 1971, 13, 387-390.

159. Pijnenburg, A.J.J.; Woodruff, G.N.; Van Rossum, J.M. Ergometrine induced locomotor activity following intracerebral injection into the nucleus accumbens. Brain Res. 1973, 59, 289-302.

160. Andrews, D.W.; Patrick, K.L.; Barchas, J.D. The effects of 5-HTP and 5-HT on dopamine release and synthesis in rat brain striatal synaptosomes. J. Neurochem. 1978, 30, 465-470.

161. De Belleroche, J.S.; Bradford, H.T. Presynaptic control of the synthesis and release of dopamine from striatal synaptosomes: a comparison between the effects of 5hydroxytryptamine, acetylcholine and glutamate. J. Neurochem. 1980, 35, 1227-1234.

162. Westerink, B.H.C.; Damsma, G.; Rollema, H.; de Vries, J.B.; Horn, A.S. Scope and limitations of in vivo brain dialysis: a comparison of its application to various neurotransmitter systems. Life Sci. 1987, 41, 1763-1776.

163. Benveniste, H.; Huettemeier, P.C. Microdialysis - Theory and application. Prog. Neurobiol. 1990, 35, 195-215.

164. Di Chiara, G. Brain dialysis of neurotransmitters: A commentary. J. Neurosci. Methods 1990, 34, 29-34.

165. Hamberger, A.; Jacobson, I.; Nystroem, B.; Sandberg, M. Microdialysis sampling of the neuronal environment in basic and clinical research. J. Intern. Med. 1991, 230, 375-380.

166. Loennroth, P. Microdialysis - A new and promising method in clinical medicine. J. Intern. Med. 1991, 230, 363-364.

167. Ungerstedt, U. Microdialysis - Principles and applications for studies in animals and man. $J$. Intern. Med. 1991, 230, 365-373.

168. Justice, J.B., Jr. Quantitative microdialysis of neurotransmitters. J. Neurosci. Methods 1993, 48, 263-276.

169. Robinson, J.E. Microdialysis: A novel tool for research in the reproductive system. Biol. Reprod. 1995, 52, 237-245.

170. Timmerman, W.; Westerink, B.H.C. Brain microdialysis of GABA and glutamate: What does it signify? Synapse 1997, 27, 242-261. 
171. Mas, M.; Gonzalez-Mora, J.L.; Hernandez, L. In vivo monitoring of brain neurotransmitter release for the assessment of neuroendocrine interactions. Cell. Mol. Neurobiol. 1996, 16, 383396.

172. Fumero, B.; Guadalupe, T.; Valladares, F.; Mora, F.; O'Neill, R.D.; Mas, M.; Gonzalez-Mora, J.L. Fixed versus removable microdialysis probes for in vivo neurochemical analysis: Implications for behavioral studies. J. Neurochem. 1994, 63, 1407-1415.

173. Peters, J.L.; Yang, H.; Michael, A.C. Quantitative aspects of brain microdialysis. Anal. Chim. Acta 2000, 412, 1-12.

174. Davies, M.I. A review of microdialysis sampling for pharmacokinetic applications. Anal. Chim. Acta 1999, 379, 227-249.

175. Stenken, J.A. Methods and issues in microdialysis calibration. Anal. Chim. Acta 1999, 379, 337-358.

176. O'Neill, R.D.; Lowry, J.P. In Encyclopedia of Analytical Chemistry; Meyers, R. (Ed.), John Wiley \& Sons Ltd., Chichester, 2000; pp. 676-709.

177. Wilson, G.S.; Hu, Y.B. Enzyme based biosensors for in vivo measurements. Chem. Rev. 2000, 100, 2693-2704.

178. Koepp, M.J.; Gunn, R.N.; Lawrence, A.D.; Cunningham, V.J.; Dagher, A.; Jones, T.; Brooks, D.J.; Bench, C.J.; Grasby, P.M. Evidence for striatal dopamine release during a video game. Nature 1998, 393, 266-268.

179. Freed, C.R.; Yamamoto, B.K. Regional brain dopamine metabolism: A marker for the speed, direction and posture of moving animals. Science 1985, 229, 62-65.

180. Fillenz, M.; O'Neill, R.D. Effects of light reversal on the circadian pattern of motor activity and voltammetric signals recorded in rat forebrain. J. Physiol. (London) 1986, 374, 91-101.

181. Walsh, J.K. Pharmacologic management of insomnia. J. Clin. Psychiat. 2004, 65, 41-45.

(C) 2005 by MDPI (http://www.mdpi.org). Reproduction is permitted for noncommercial purposes. 